\begin{tabular}{c} 
Tersedia online di: http://ejournal-balitbang.kkp.go.id/index.php/bawal \\
e-mail:bawal.puslitbangkan@ gmail.com \\
BAWAL WIDYA RISET PERIKANAN TANGKAP \\
Volume 12 Nomor 1 April 2020 \\
p-ISSN: 1907-8226 \\
e-ISSN: 2502-6410 \\
BAWAL \\
Nomor Akreditasi Kementerian RISTEKDIKTI: 21/E/KPT/2018 \\
\hline \hline
\end{tabular}

\title{
DUGAAN MUSIM PEMIJAHAN IKAN CAKALANG (Katsuwonus pelamis) DI PERAIRAN SAMUDRA HINDIA SELATAN JAWA DAN NUSA TENGGARA
}

\section{SPAWNING ESTIMATION OF SKIPJACK TUNA (Katsuwonus pelamis) IN THE INDIAN OCEAN SOUTH OF JAVA AND NUSA TENGGARA}

\author{
Yoke Hany Restiangsih*1, Anthony Sisco Panggabean ${ }^{1}$ dan Erfind Nurdin ${ }^{1}$ \\ ${ }^{1}$ Peneliti pada Balai Riset Perikanan Laut - Jl. Raya Bogor KM. 47, Nanggewer - Cibinong, Jawa Barat, Indonesia \\ Teregistrasi I tanggal: 28 Februari 2020; Diterima setelah perbaikan tanggal: 03 Juli 2020; \\ Disetujui terbit tanggal: 07 Juli 2020
}

\begin{abstract}
ABSTRAK
Sumberdaya ikan cakalang (Katsuwonus pelamis) merupakan ikan ekonomis penting dan utama di Indonesia. Tingginya tingkat pemanfaatan ikan cakalang di Samudra Hindia menjadi hal yang sangat rawan dan perlu kehatihatian dalam pengelolaannya. Tersedianya data dan informasi tentang musim pemijahan merupakan bagian dari pengetahuan yang diperlukan untuk mengetahui status sumberdaya bagi upaya pengelolaannya. Penelitian ikan cakalang dilakukan berdasarkan pengambilan contoh biologi dibeberapa tempat pendaratan ikan (Palabuhan Ratu, Prigi dan Labuhan Lombok). Penelitian dilaksanakan pada bulan Januari sampai dengan Nopember 2016. Pendugaan musim pemijahan menggunakan pendekatan indeks kematangan gonad (IKG) bulanan. Distribusi ukuran ikan yang tertangkap dengan menggunakan pancing tonda berkisar antara $24-66 \mathrm{~cm}$. Ukuran rata-rata pertama kali tertangkap (Lc) pada panjang 41,6 cm, ukuran pertama kali matang gonad (Lm) 42,5 cm. Berdasarkan fluktuasi IKG musim pemijahan ikan diduga berlangsung pada bulan April dan Nopember.
\end{abstract}

Kata Kunci: Musim pemijahan; Katsuwonus pelamis; Samudra Hindia

\section{ABSTRACT}

Skipjack tuna (Katsuwonus pelamis) are most important and economically fish in Indonesia. The highest exploitation skipjack in the Indian Ocean is very vulnerable are requires caution in its management. The availability of data and information about the spawning season is a part of the knowledge needed to determine the status of resources for management efforts. This research was carried out based on biological sampling at several fish landing sites (Palabuhanratu, Prigi, and Labuhan Lombok). This research was conducted from January until to November 2016. Estimating of the spawning season was used a monthly Gonado Somatic Index (GSI) approach. The range of size distribution from of fish caught using troll line were 24 until $66 \mathrm{~cm}$. The average size of first caught $\left(L_{50 \%}\right)$ at a length was $41.6 \mathrm{~cm}$, the size of the length of first maturity $(\mathrm{Lm})$ was 42,5 $\mathrm{cm}$. Based on the GSI fluctuation, spawning season was done in April and November.

\section{Keywords: Spawning season; Katsuwonus pelamis; Indian Ocean}

\section{PENDAHULUAN}

Sumberdaya ikan di Indonesia pada tahun 2016 sebesar 5.268.806 ton, dengan prosentase ikan pelagis besar sebesar $27,8 \%$ (1.466.328 ton) dari total produksi, dan ikan cakalang sebesar $30 \%$ (440.812 ton) dari total produksi ikan pelagis besar nasional tahun 2016 (Anonimus, 2017). Komoditas ikan pelagis besar diwilayah Pengelolaan Perikanan Nasional Republik Indonesia (WPP NRI) 573 Samudra Hindia merupakan salah satu komoditas penting perikanan Indonesia yang sudah dieksploitasi sejak lama. Salah satu ikan pelagis besar yang banyak tertangkap di WPP NRI 573 yaitu cakalang (Katsuwonus pelamis), produksi ikan cakalang di WPP NRI 573 pada tahun 2016 sebesar 37.792 ton (Anonimus, 2017).

Ikan cakalang (Katsuwonus pelamis), merupakan spesies yang bermigrasi luas (highly migratory species) dan menempati perairan tropis maupun sub-tropis Arai $e t$ al. (2005). Distribusi, pergerakan dan kerentanannya 
dipengaruhi oleh habitat yang disukainya. Keberadaan mangsa, temperature yang sesuai dan oksigen yang mencukupi sangat berpengaruh nyata terhadap kelangsungan hidup ikan cakalang. Sebagai konsekwensinya, distribusi spasial ikan cakalang bersifat musiman dan berpola tahunan (Mugo et al., 2010).

Secara komersial ikan cakalang ditangkap dengan menggunakan pukat cincin (purse seine), jaring insang (gill net), pancing tonda (troll line), huhate (pole and line), dan pancing ulur (handline). Menurut Dueri et al. (2012). Ikan cakalang terdistribusi secara merata di Samudra Hindia, termasuk diwilayah Indonesia. Hasil tangkapan ikan cakalang adalah 50\% dari total tangkapan ikan tuna tropis (tropical tuna) di Samudra Hindia (Rochman et al., 2015). Penyebaran cakalang di perairan Indonesia meliputi Samudra Hindia (perairan Barat Sumatra, Selatan Jawa, Bali dan Nusa Tenggara), perairan Indonesia bagian timur (Laut Sulawesi, Maluku, Arafuru, Banda, Flores dan Selat Makassar) dan Samudra Pasifik (Uktolseja, 1989).

Rochman et al. (2015) menyatakan adanya pemanfaatan ikan cakalang di Samudra Hindia khususnya di wilayah teritori Indonesia secara terus menerus mengakibatkan tingkat pemanfaatan cakalang berada pada kondisi optimum sehingga perlu kehati-hatian dan ketepatan dalam pengelolaannya. Menurut IOTC (2016), secara umum status stok ikan cakalang tahun 2014 di Samudra Hindia berada pada kondisi yang baik dan belum terjadi lebih tangkap. Salah satu aspek untuk mendukung upaya pengelolaan sumberdaya ikan adalah pengetahuan dasar mengenai aspek biologi reproduksi (Jatmiko et al., 2015) dan musim pemijahan (Suwarso et al., 2015).

Tulisan ini membahas tentang dugaan pemijahan ikan cakalang dan diharapkan informasi tersebut dapat menjadi pertimbangan dalam pengelolaan perikanan ikan cakalang khususnya di Samudra Hindia Selatan Jawa dan Nusa Tenggara. Informasi musim pemijahan ditentukan berdasarkan indeks kematangan gonad (IKG), tingkat kematangan gonad (TKG), ukuran pertama kali matang gonad (Lm), komposisi ukuran, dan Panjang ikan rata-rata kumulatif $50 \%$ (Lc).

\section{BAHANDANMETODE Waktu dan Lokasi Pengambilan Contoh}

Pengumpulan contoh ikan cakalang (Katsuwonus pelamis) dilakukan di beberapa tempat pendaratan yaitu Pelabuhan Perikanan Nusantara (PPN) Palabuhan Ratu, PPN Prigi dan Pelabuhan Perikanan Pantai (PPP) Labuhan Lombok, Januari sampai dengan Nopember 2016. Data diperoleh dari hasil pengukuran yang dilakukan oleh peneliti dan enumerator di lapangan. Sebanyak 6.514 contoh ikan yang berasal dari hasil tangkapan pancing tonda. Pengamatan jenis kelamin, tingkat kematangan gonad dan indeks kematangan gonad dilakukan sebanyak 240 contoh ikan pada bulan Januari, Februari, Maret, April, Mei, Juni, Juli, Agustus dan Nopember. Sampel ikan terpilih diukur panjang cagak (Fork length, FL) dengan menggunakan papan ukur berketelitian $1 \mathrm{~mm}$, serta ditimbang beratnya dengan timbangan digital berketelitian 1,0 g. Pengamatan tingkat kematangan gonad dilakukan di lapangan, kemudian diidentifikasi dan ditimbang beratnya menggunakan timbangan digital berketelitian 0,01 g.

Analisis hubungan panjang-bobot bertujuan untuk menentukan pola pertumbuhan ikan di alam dan dihitung dengan persamaan dari Bal \& Rao, (1984).

$\mathrm{W}=\mathrm{aL}^{\mathrm{b}}$

Keterangan:

$\mathrm{W}=$ bobot ikan $(\mathrm{g})$

$\mathrm{L}$ = panjang cagak ikan $(\mathrm{cm}), \mathrm{a}$ dan $\mathrm{b}$ adalah konstanta regresi

Uji t $(\mathrm{p}<0,05)$ digunakan untuk menguji apakah nilai b $=3$ atau tidak. Jika $\mathrm{b}=3$ berarti ikan mempunyai pola pertumbuhan isometrik dan sebaliknya bila $b \neq 3$ berarti pola pertumbuhan ikan bersifta alometrik (Effendie 2002).

Penentuan nisbah kelamin dilakukan dengan menghitung jumlah ikan jantan dan ikan betina yang tertangkap dengan menggunakan rumus, yaitu:

$\mathrm{X}=\frac{M}{F}$

Keterangan:

$\mathrm{X}=$ nisbah kelamin,

$\mathrm{M}=$ jumlah ikan jantan (ekor)

$\mathrm{F}=$ jumlah ikan betina (ekor)

Selanjutnya untuk menguji keseimbangan nisbah kelamin menggunakan rumus Chi-square (Steel \& Torrie 1981).

$\mathrm{X}^{2}=\sum_{i=1}^{n} \frac{(o i-e i)^{2}}{e i}$

Keterangan: $\mathrm{X}^{2}=$ chi-square (Nilai perubah acak $\mathrm{X}^{2}$ yang sebaran penarikan contohnya mendekati sebaran chi-kuadrat), oi = Frekuensi ikan jantan atau betina ke-I yang diamati, ei = jumlah frekuensi harapan dari ikan jantan dan ikan betina yang frekuensi ikan jantan ditambah frekuensi ikan betina dibagi dua.

Dalam pengujian hipotesis pada penolakan atau penerimaan $\mathrm{H}_{0}$ berdasarkan nilai $\mathrm{X}^{2}$ tabel (nilai acuan), mempunyai kriteria sebagai berikut: Jika nilai $\mathrm{X}^{2}$-hitung > $\mathrm{X}^{2}$-tabel, maka $\mathrm{H}_{0}$ ditolak, yang berarti rasio kelamin ikan jantan dan ikan betina tidak seimbang; jika nilai $\mathrm{X}^{2}$-hitung 
$<\mathrm{X}^{2}$-tabel, maka $\mathrm{H}_{0}$ diterima, yang berarti rasio kelamin ikan jantan dan ikan betina seimbang.

Pemeriksaan tingkat kematangan gonad (TKG), diamati secara visual dengan cara melihat perubahan morfologi

Tabel 1. Deskripsi tingkat kematangan gonad

Table 1. Description of gonado maturity stages gonad. Perkembangan gonad dibagi menjadi lima stadium berdasarkan Holden \& Raitt, (1974) seperti yang tertera pada Tabel 1.

\begin{tabular}{|c|c|c|}
\hline TKG & Kategori & Keterangan \\
\hline $\mathrm{I}$ & Belum matang & $\begin{array}{l}\text { Ovarium dan testis sekitar } 1 / 3 \text { panjang rongga perut. Ovarium berwarna } \\
\text { merah jambu, transparan, sedangkan testis keputih-putihan dan telur tidak } \\
\text { dapat dilihat dengan mata telanjang. }\end{array}$ \\
\hline II & Perkembangan & $\begin{array}{l}\text { Ovarium dan testis sekitar } 2 / 3 \text { panjang rongga perut. Ovarium berwarna } \\
\text { merah jambu, jernih dan transparan, sedangkan testis berwarna keputihan, } \\
\text { bentuknya tidak simetris dan telur tidak dapat dilihat dengan mata } \\
\text { telanjang. }\end{array}$ \\
\hline III & Pematangan & $\begin{array}{l}\text { Ovarium berwarna merah jambu, kekuningan dan terlihat butiran kecil, } \\
\text { sedangkan testis berwarna putih krem dengan telur transparan dan dapat } \\
\text { diamati dengan mata telanjang. }\end{array}$ \\
\hline IV & Bunting/matang & $\begin{array}{l}\text { Ovarium dan testis sekitar } 2 / 3 \text { sampai memenuhi rongga perut. Ovarium } \\
\text { berwarna coklat kemerahan, banyak diliputi pembuluh darah dan telur } \\
\text { dapat diamati dengan mata telanjang, sedangkan testis halus dan berwarna } \\
\text { putih agak krem. }\end{array}$ \\
\hline V & Memijah & $\begin{array}{l}\text { Ovarium dan testis berkurang sampai } 1 / 2 \text { panjang rongga perut. Pada } \\
\text { lapisan dinding masih tersisa telur matang, sedangkan testis bertekstur } \\
\text { lembek dan pendek. }\end{array}$ \\
\hline
\end{tabular}

Sumber: Holden \& Raitt, (1974).

Perhitungan nilai ukuran panjang ikan rata-rata kumulatif 50\% (Lc) diperoleh dengan cara memplotkan frekuensi kumulatif ikan yang tertangkap (Y) dengan panjang cagak (X), akan diperoleh kurva logistik baku. Titik perpotongan antara kurva logistik baku dengan 50\% frekuensi kumulatif merupakan nilai rata-rata panjang ikan yang tertangkap (Wujdi et al., 2013; Wahyuningsih et al., 2013) dihitung dengan persamaan (Jones, 1976 dalam Sparre \& Venema, 1999):

$$
\begin{aligned}
& S_{L} \text { est }=\frac{1}{1+\exp \left(S_{1}-S_{2} * L\right)} . \\
& \operatorname{Ln}\left[\frac{1}{S L}-1\right]=S_{1}-S_{2} * L \ldots \ldots \ldots \ldots \ldots \ldots \ldots \ldots \ldots \ldots \ldots \ldots
\end{aligned}
$$

Keterangan:

SL = kurva logistik (selektivitas alat tangkap berbasis panjang)

$\mathrm{S}_{1}$ dan $\mathrm{S}_{2}=$ konstanta a dan b pada rumus kurva logistik

Ukuran ikan pertama kali matang gonad (Lm) ditentukan dengan memplotkan persentase ikan matang gonad dengan panjang totalnya. Panjang ikan minimum pada sekurang-kurangnya 50\% dari ikan yang matang gonad (TKG IV dan V) dinyatakan sebagai ukuran ikan pertama kali matang gonad (Rao \& Sharma, 1984; Offem et al., 2008). Pendugaan nilai Lm dilakukan sesuai dengan prosedur penghitungan dari Spearman - Karber yang dilakukan oleh Udupa (1986) dalam Saputra (2005) sebagai berikut :

$\mathrm{m}=\mathrm{X}_{\mathrm{k}}+\mathrm{X} / 2-\left(\mathrm{X} \sum \mathrm{P}_{\mathrm{i}}\right)$

Keterangan: $\mathrm{m}=$ logaritma ukuran ikan saat pertama matang gonad, $\mathrm{Xk}=$ logaritma ukuran ikan dimana $100 \%$ ikan sampel sudah matang $\left(\mathrm{P}_{\mathrm{i}}=1\right), \mathrm{X}=$ selisih logaritma ukuran nilai tengah panjang, $\mathrm{P}_{\mathrm{i}}=$ proporsi ikan matang pada kelompok ke-i. Rata-rata ukuran ikan pertama matang gonad diperoleh dari nilai antilog-m.

Musim pemijahan diidentifikasi berdasarkan temporal trends dari kematangan gonad dan indeks kematangan gonad (IKG) kemudian dianalisis dengan rumus IKG dari Afonso-Dias et al. (2005):

$\mathrm{IKG}=\frac{G w}{W} \times 100 \%$

Keterangan : IKG = Indeks kematangan gonad, $\mathrm{Gw}=$ berat gonad (gram), $\mathrm{W}=$ berat total individu ikan (gram). 


\section{HASIL DAN BAHASAN Hasil}

\section{Sebaran Ukuran dan Hubungan Panjang Bobot}

Struktur ukuran panjang cagak pada ikan cakalang (Katsuwonus pelamis) dalam satu tahun di Samudra Hindia Selatan Jawa dan Nusa Tenggara dari 6.514 ekor berkisar antara 24 - $66 \mathrm{~cm}$ dengan modus pada nilai tengah $39 \mathrm{~cm}$ (Gambar 1).

Hasil analisa hubungan panjang-bobot ikan cakalang menunjukkan persamaan $\mathrm{W}=0,010 \mathrm{~L}^{3,145}$ dengan nilai koreksi $\left(r^{2}\right)$ sebesar 0,94\% (Gambar 2). Setelah dilakukan uji-t tingkat kepercayaan $95 \%(\alpha=0,05)$ didapatkan pola pertumbuhan bersifat alometrik positif. Pola pertumbuhan alometrik positif artinya pertambahan berat lebih cepat dibanding pertambahan panjang.

\section{Nisbah Kelamin}

Jumlah contoh ikan yang dikumpulkan setiap bulannya berkisar antara 10-50 ekor. Secara keseluruhan, total contoh ikan cakalang adalah 240 ekor yang terdiri atas 105 ekor ikan jantan dan 135 ekor ikan betina. Secara umum, nisbah kelamin ikan cakalang jantan dan betina adalah $1: 1,28$ atau $44 \%$ ikan jantan berbanding $56 \%$ ikan betina (Tabel 2). Berdasarkan perhitungan, diperoleh nilai chi square sebesar 4,92 lebih besar daripada nilai tabel pada selang kepercayaan $95 \%(3,84)$. Nilai ini menunjukkan bahwa terdapat perbedaan antara jumlah ikan jantan dan betina yang muncul.

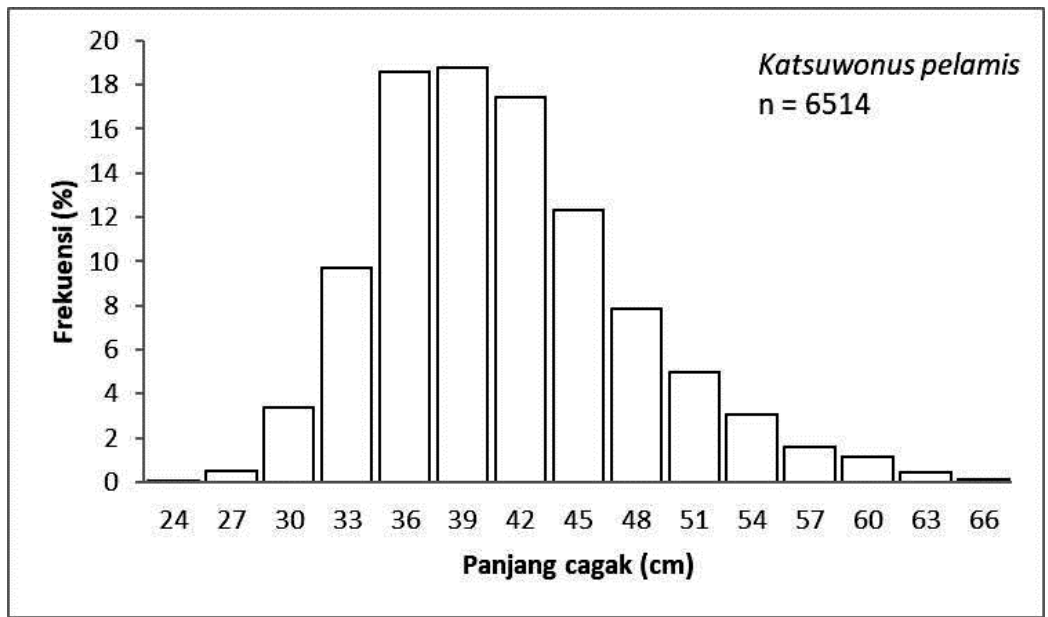

Gambar 1. Sebaran frekuensi panjang cagak ikan cakalang (Katsuwonus pelamis) yang tertangkap pancing tonda di Samudra Hindia Selatan Jawa dan Nusa Tenggara, Januari - Nopember 2016.

Figure 1. Fork length distribution of Skipjack tuna caught by troll line in the Indian Ocean South of Java and Nusa Tenggara, January-November 2016.

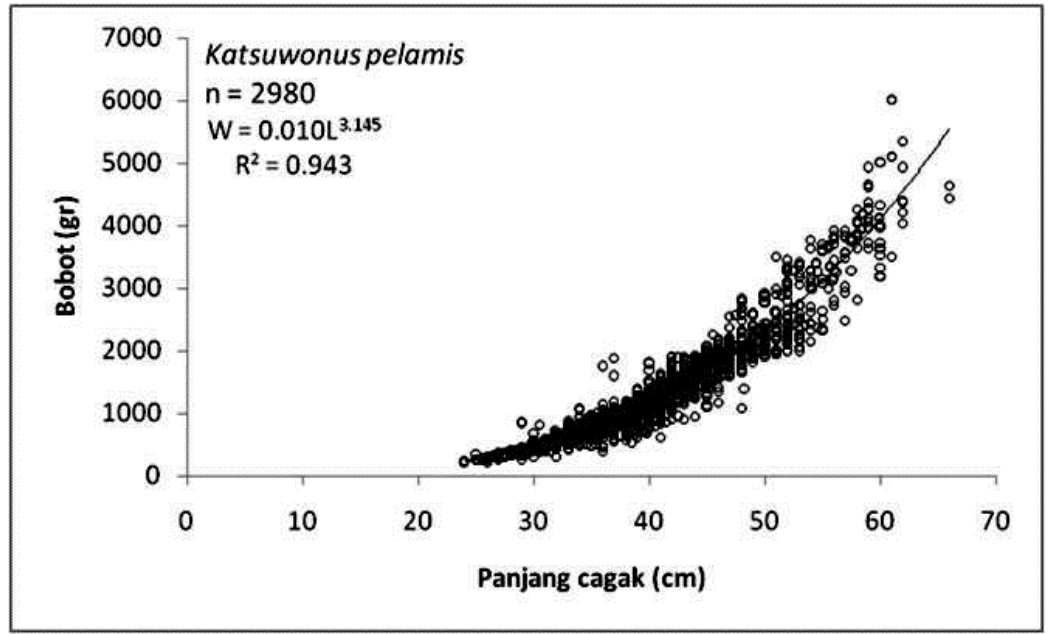

Gambar 2. Hubungan panjang-bobot ikan cakalang (Katsuwonus pelamis) yang tertangkap pancing tonda di Samudra Hindia Selatan Jawa dan Nusa Tenggara, Januari - Nopember 2016.

Figure 2. Length-weight relationship of Skipjack tuna caught by troll line in the Indian Ocean South of Java and Nusa Tenggara, January-November 2016. 
Tabel 2. Nisbah kelamin bulanan ikan cakalang (Katsuwonus pelamis) yang tertangkap pancing tonda di Samudra Hindia Selatan Jawa dan Nusa Tenggara, Januari - Nopember 2016

Table 2. Monthly sex ration of Skipjack tuna caught by troll line in the Indian Ocean South of Java and Nusa Tenggara, January-November 2016.

\begin{tabular}{lccc}
\hline \multicolumn{1}{c}{ Bulan } & Jantan (ekor) & Betina (ekor) & Nisbah kelamin \\
\hline Januari & 9 & 6 & $1: 0,67$ \\
Febuari & 14 & 15 & $1: 1,07$ \\
Maret & 20 & 15 & $1: 0,75$ \\
April & 10 & 11 & $1: 1,1$ \\
Mei & 9 & 13 & $1: 1,44$ \\
Juni & 6 & 30 & $1: 5$ \\
Juli & 6 & 5 & $1: 0,83$ \\
Agustus & 21 & 31 & $1: 1,48$ \\
Nopember & 10 & 9 & $1: 0,9$ \\
Jumlah & 105 & 135 & $1: 1,28$ \\
\hline
\end{tabular}

\section{Tingkat Kematangan Gonad}

Tingkat kematangan gonad (TKG) ikan jantan dan betina diamati berdasarkan perubahan morfologi testis dan ovariumnya. Tabel 3 menunjukkan perubahan TKG pada setiap bulan pengamatan.

Tabel 3. memperlihatkan bahwa Ikan Jantan TKG I banyak ditemukan pada bulan Februari, Mei, Juni dan Nopember, TKG II banyak dtemukan pada bulan April, TKG III banyak ditemukan pada bulan Januari dan TKG
IV banyak ditemukan pada bulan Maret, Juli, dan Agustus. Sedangkan ikan betina TKG I banyak ditemukan pada bulan Januari, Februari, Juni, dan Nopember, TKG II banyak ditemukan pada bulan Juni, TKG III banyak ditemukan pada bulan Januari, dan TKG IV banyak ditemukan pada bulan Maret, April, Mei, Juli, dan Agustus. TKG IV dikategorikan sebagai ikan yang sudah matang atau ikan dewasa yang siap untuk memijah, sedangkan TKG V baik pada ikan jantan maupun ikan betina selama penelitian berlangsung tidak ditemukan, yang mana TKG V merupakan ikan yang sudah memijah.

Tabel3. Persentase tingkat kematangan gonad ikan cakalang (Katsuwonus pelamis) yang tertangkap pancing tonda di Samudra Hindia Selatan Jawa dan Nusa Tenggara, Januari - Nopember 2016.

Table 3. Maturation of gonads and testes of Skipjack tuna caught by troll line in the Indian Ocean South of Java and Nusa Tenggara, January-November 2016.

\begin{tabular}{|c|c|c|c|c|c|c|c|c|c|c|}
\hline \multirow{3}{*}{$\begin{array}{c}\text { Bulan } \\
\text { Pengamatan }\end{array}$} & \multicolumn{10}{|c|}{ Tingkat Kematangan Gonad (\%) } \\
\hline & \multicolumn{5}{|c|}{ Jantan } & \multicolumn{5}{|c|}{ Betina } \\
\hline & I & II & III & IV & $\mathbf{V}$ & I & II & III & IV & V \\
\hline Januari & 11.11 & 11.11 & 66.67 & 11.11 & - & 33.33 & 16.67 & 33.33 & 16.67 & - \\
\hline Februari & 57.14 & 28.57 & - & 14.29 & - & 66.67 & - & 13.33 & 20.00 & - \\
\hline Maret & 20.00 & 5.00 & 30.00 & 45.00 & - & 13.33 & 13.33 & 6.67 & 66.67 & - \\
\hline April & 10.00 & 50.00 & 20.00 & 20.00 & - & 9.09 & 36.36 & 9.09 & 45.45 & - \\
\hline Mei & 55.56 & 11.11 & 11.11 & 22.22 & - & 15.38 & 15.38 & 7.69 & 61.54 & - \\
\hline Juni & 50.00 & 16.67 & - & 33.33 & - & 36.67 & 40.00 & 3.33 & 20.00 & - \\
\hline Juli & - & - & - & 100.00 & - & - & - & 20.00 & 80.00 & - \\
\hline Agustus & 38.10 & 14.29 & 9.52 & 38.10 & - & 16.13 & 32.26 & 16.13 & 35.48 & - \\
\hline Nopember & 80.00 & 20.00 & - & - & - & 77.78 & 22.22 & - & - & - \\
\hline
\end{tabular}

Pendugaan Ukuran Panjang Rata-Rata Kumulatif 50\% (Lc)

Panjang rata-rata kumulatif 50\% (Lc) ikan cakalang yang tertangkap dengan pancing tonda di Samudra Hindia Selatan Jawa dan Nusa Tenggara diperoleh nilai $\mathrm{Lc}=41,6$ $\mathrm{cm}$ (Gambar 3).

\section{Ukuran Pertama Kali Matang Gonad (Lm)}

Hasil penelitian didapatkan ikan cakalang yang berada pada TKG IV mulai dijumpai pada ikan dengan panjang cagak $33 \mathrm{~cm}$, sedangkan ikan dengan TKG IV didominasi pada ikan dengan panjang cagak $42 \mathrm{~cm}$ (Gambar 4). 


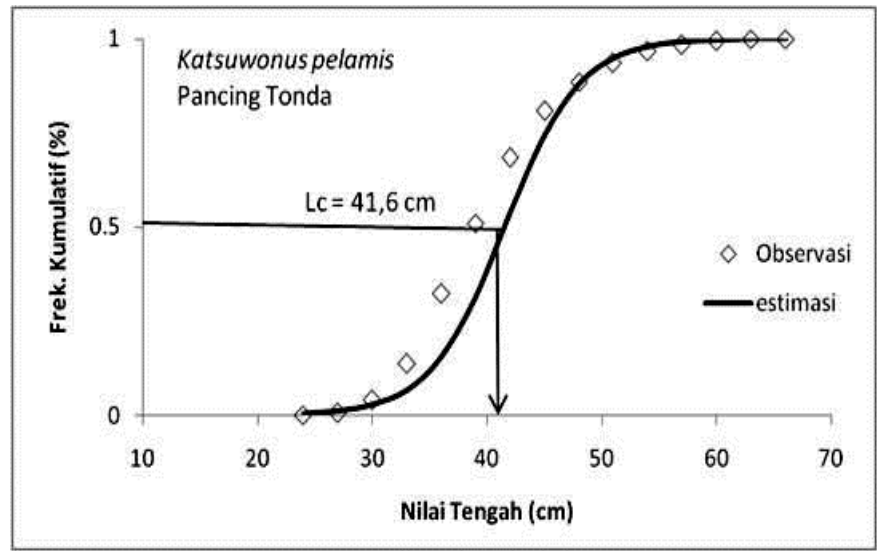

Gambar 3. Panjang rata-rata kumulatif 50\% (Lc) ikan cakalang cakalang (Katsuwonus pelamis) yang tertangkap pancing tonda di Samudra Hindia Selatan Jawa dan Nusa Tenggara, Januari - Nopember 2016.

Figure 3. Average length cumulatif $50 \%(\mathrm{Lc})$ of skipjack tuna caught by troll line in the Indian Ocean South of Java and Nusa Tenggara, January-November 2016.

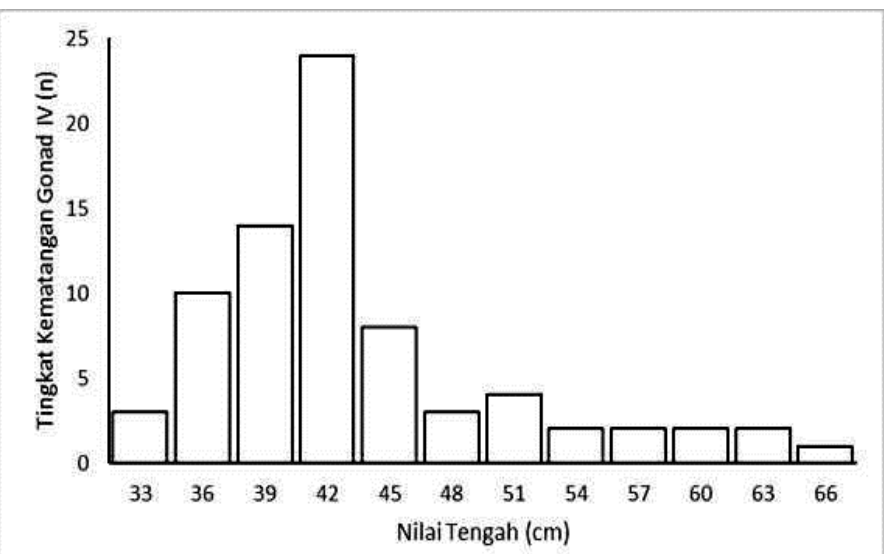

Gambar 4. Hubungan ukuran dan tingkat kematangan gonad IV pada ikan cakalang yang tertangkap pancing tonda di Samudra Hindia Selatan Jawa dan Nusa Tenggara, Januari - Nopember 2016.

Figure 4. Length and Maturation of gonads stage IV relationship of Skipjack tuna caught by troll line in the Indian Ocean South of Java and Nusa Tenggara, January-November 2016.

Ukuran panjang pertama kali matang gonad (Lm)ikan Samudra Hindia Selatan Jawa dan Nusa Tenggara cakalang yang tertangkap dengan pancing tonda di diperoleh nilai 42,5 cm (Gambar 5).

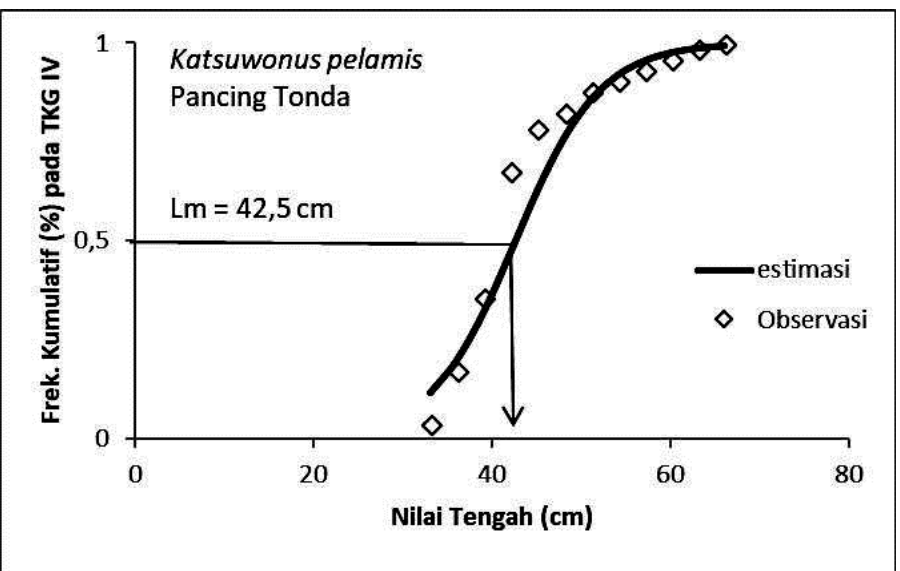

Gambar 5. Ukuran pertama kali matang gonad (Lm) ikan cakalang cakalang (Katsuwonus pelamis) yang tertangkap pancing tonda di Samudra Hindia Selatan Jawa dan Nusa Tenggara, Januari - Nopember 2016.

Figure 5. Length maturity (Lm) of skipjack tuna caught by troll line in the Indian Ocean South of Java and Nusa Tenggara, January-November 2016. 


\section{Indeks Kematangan Gonad}

Hasil observasi makroskopis terhadap nilai rata-rata indeks kematangan gonad (IKG) ikan cakalang adalah
$1,23 \%(0,13-2)$. Sebaran IKG tiap bulan pengamatan menunjukkan bahwa terdapat dua (2) puncak yang terjadi yaitu pada bulan Maret dan Agustus dengan nilai IKG maksimum 7,7\% dan 5\% (Gambar 6).

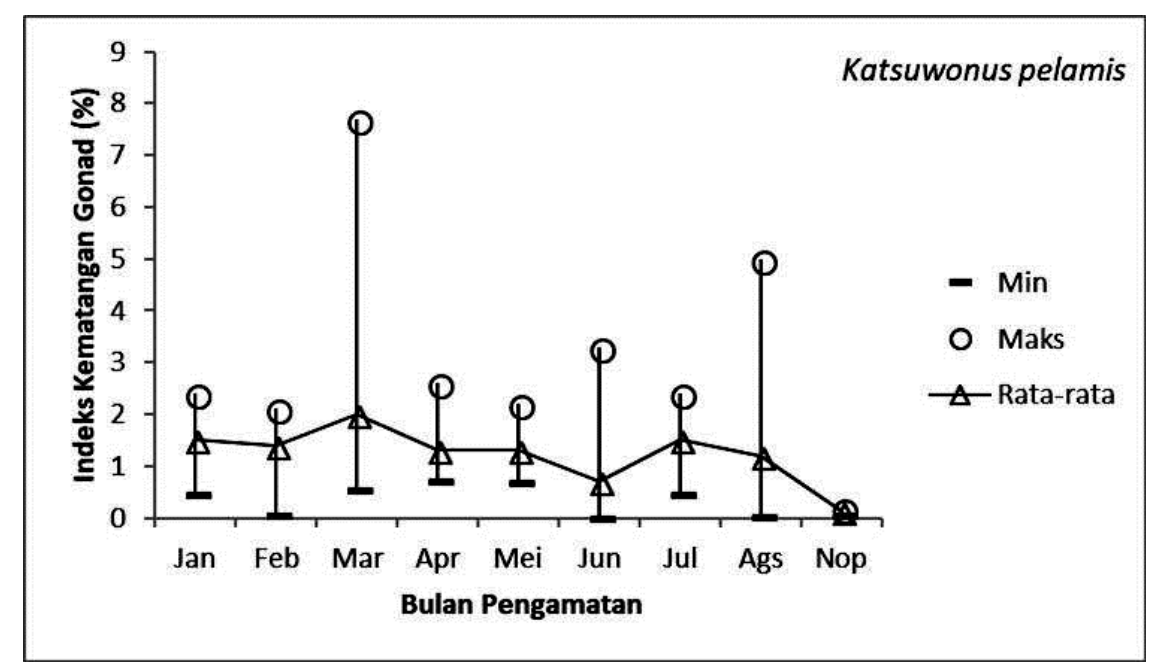

Gambar 6. Indeks kematangan gonad (IKG) ikan cakalang cakalang (Katsuwonus pelamis) yang tertangkap pancing tonda di Samudra Hindia Selatan Jawa dan Nusa Tenggara, Januari - Nopember 2016.

Figure 6. Gonado somatic index (GSI)of skipjack tuna caught by troll line in the Indian Ocean South of Java and Nusa Tenggara, January-November 2016.

\section{Bahasan}

Hasil pengamatan kisaran panjang ikan cakalang yang tertangkap pancing tonda di Samudra Hindia Selatan Jawa dan Nusa Tenggara diperoleh panjang cagak kisaran 24 $66 \mathrm{~cm}$ dengan modus pada panjang $39 \mathrm{~cm}$. Pola pertumbuhan bersifat alometrik positif yang berarti bahwa pertumbuhan bobot individu lebih cepat dibandingkan dengan pertumbuhan panjang. Kondisi yang sama ditemukan juga pada cakalang yang tertangkap di perairan Laut Flores (Restiangsih \& Amri, 2018), PPN Palabuhan Ratu (Nurdin \& Panggabean, 2017), dan Bitung, Sulawesi Utara (Nugraha \& Mardlijah, 2008). Sedangkan hasil penelitian Nurdin et al., 2012) di perairan Prigi, Jawa Timur menyatakan pola pertumbuhan ikan cakalang bersifat alometrik negatif dan Jamal et al. (2011) menyebutkan pola pertumbuhan ikan cakalang yang tertangkap di perairan Teluk Bone bersifat isometrik. Faktor-faktor yang menyebabkan perbedaan pola pertumbuhan adalah perbedaan jumlah dan variasi ukuran ikan yang diamati (Restiangsih \& Amri, 2018). Effendie (2002) menyatakan perbedaan sifat pertumbuhan ikan dipengaruhi oleh keturunan, penyakit, ketersediaan makanan, dan habitat. Sedangkan King (2007) menyatakan bahwa hubungan panjang bobot dapat digunakan untuk menentukan kemungkinan perbedaan antara jenis ikan yang sama pada stok yang berbeda.

Suwarso et al. (2015) berpendapat bahwa perbandingan nisbah kelamin bermanfaat dalam pendugaan 'spawning biomass' dari stok alam serta diharapkan dapat diperoleh suatu refference points sebagai bahan masukan bagi pengelolaan sumberdaya ikan. Nisbah kelamin ikan cakalang jantan terhadap betina secara keseluruhan sebagai 1:1,28. Hasil uji chi square, nisbah kelamin jantan dan betina berdasarkan waktu penelitian berbeda nyata pada taraf kepercayaan $95 \%\left(X_{\text {hitung }}^{2}>X_{\text {tabel }}^{2}\right)$ yang berarti bahwa nisbah kelamin ikan cakalang betina lebih besar dari ikan jantan. Ikan betina yang lebih dominan tertangkap mengindikasikan bahwa kelestarian suatu populasi masih dapat dipertahankan, sebab menurut Sulistiono et al. (2001) jika rasio ikan betina lebih banyak jumlahnya di perairan populasi masih dapat dipertahankan di perairan, dan menurut Saputra et al. (2009) dengan rasio yang demikian mengakibatkan peluang pembuahan sel telur oleh spermatozoa sampai menjadi individu baru akan semakin besar.

Rata-rata ukuran kumulatif 50\% (Lc) pada penelitian ini sebesar 41,6 cm. Hasil penelitian Rochman et al., 2015; Zedta et al., 2017; dan Nurdin \& Panggabean, 2017 di Samudra Hindia Selatan Jawa didapatkan nilai Lc masingmasing sebesar 38,73; 39,4; dan $40 \mathrm{~cm}$. Sedangkan hasil penelitian Hidayat et al., 2017 di Samudra Pasifik Lc sebesar $40,1 \mathrm{~cm}$. Perbedaan nilai panjang pertama kali tertangkap pada setiap wilayah sangat dipengaruhi oleh alat tangkap yang digunakan. Rata-rata ukuran pertama kali matang gonad $\left(\mathrm{L}_{\mathrm{m}}\right)$ pada penelitian ini sebesar $42,5 \mathrm{~cm}$. Hasil penelitian Nikijuluw (2009) dan Jatmiko et al. (2015) di Samudra Hindia dilaporkan bahwa ukuran pertama kali matang gonad ikan cakalang masing-masing 41-43 cm adalah 42,9 cm. Indian Ocean Tuna Commission (2013) melaporkan bahwa ukuran panjang pertama kali matang 
gonad $\left(\mathrm{L}_{\mathrm{m}}\right)$ cakalang adalah $44 \mathrm{~cm}$ dan ukuran panjang pertama kali matang gonad $\left(\mathrm{L}_{\mathrm{m}}\right)$ di Samudra Hindia Bagian Barat yaitu 37,8 cm (Grande et al., 2010) dan 44,7 cm di Samudra Hindia Selatan Bali (Hartaty \& Arnenda, 2019). Menurut Udupa (1986), perbedaan hasil tersebut dapat terjadi karena dalam spesies yang sama juga terdapat kemungkinan mengalami ukuran panjang pertama kali matang gonad yang berbeda dan berkaitan dengan kesesuaian kondisi lingkungannya (Lambert et al., 2003). Pada penelitian ini ikan cakalang yang tertangkap di Samudra Hindia Selatan Jawa dan Nusa Tenggara sebagian belum mencapai matang gonad. Kondisi dimana banyaknya ikan-ikan muda yang tertangkap akan beresiko terhadap keseimbangan stok ikan tersebut.

Tingkat kematangan gonad (TKG) adalah tahap tertentu perkembangan gonad sebelum dan sesudah ikan memijah, terutama untuk betina, sedangkan IKG merupakan nilai dalam \% sebagai hasil perbandingan berat gonad dan berat tubuh ikan (Rachmawati \& Hartati, 2017). Pertumbuhan IKG akan sama/proposional dengan TKG dan menjadi maksimal pada saat akan terjadi pemijahan (Effendie, 2002). Pada penelitian ini TKG III dan TKG IV yang merupakan kondisi matang gonad atau ikan mature atau ikan yang siap memijah ditemukan pada bulan Januari, Maret, April, Mei, Juli, dan Agustus, hal tersebut menunjukkan bahwa kelompok ikan cakalang mengalami kematangan gonad yang tidak bersamaan sehingga diduga pemijahannya bersifat bertahap (partial spawner). Hal ini diperkuat dengan nilai IKG bulanan ikan cakalang ditemukan dua (2) puncak yaitu pada Maret dan Agustus, sehingga musim pemijahan diduga berlangsung pada bulan April dan Nopember, hal ini diduga terjadinya pelepasan telur (memijah) sehingga berat gonad mengalami penurunan dan nilai IKG juga menurun. Nilai IKG pada saat akan memijah semakin tinggi dan setelah memijah akan menurun sampai selesai memijah (Effendie, 1997). Ikan cakalang merupakan ikan oseanik sehingga dapat diasumsikan bahwa ikan siap untuk memijah bermigrasi keluar dari fishing ground menuju spawning ground sehingga pada penelitian ini ikan dengan TKG V (spent) tidak ditemukan. Berdasarkan hasil tersebut diduga bahwa musim pemijahan ikan cakalang di Samudra Hindia Selatan Jawa dan Nusa Tenggara terjadi pada April dan Nopember. Menurut Widodo (1986) dalam Mardijah dan Patria (2012), bahwa musim pemijahan terjadi satu bulan setelah persentase tertinggi ikan yang matang gonad. Hal ini serupa dengan pernyataan Restiangsih \& Amri (2018) bahwa pemijahan ikan cakalang di Perairan Laut Flores terjadi secara bertahap dan musim pemijahan ikan cakalang di Samudra Hindia terjadi pada bulan November (Jatmiko et al., 2015) dan Desember (Froese \& Pauly, 2011). Musim pemijahan ikan dipengaruhi oleh faktor internal dan faktor eksternal. Faktor internal antara lain spesies, umur dan ketersediaan hormon, sedangkan faktor eksternal antara lain suhu perairan dan jenis makanan (Effendie, 2002).

\section{KESIMPULAN}

Pada penelitian ini didapatkan perbandingan ikan cakalang jantan dan betina yaitu 1 : 1,28 yang mengindikasikan bahwa kelestarian suatu populasi masih dapat dipertahankan. Pola pemijahan ikan cakalang di perairan Samudra Hindia Selatan Jawa dan Nusa Tenggara dilakukan secara bertahap (partial spawner), dengan dugaan awal musim pemijahan (spent) terjadi pada April dan Nopember. Panjang pertama kali tertangkap dan panjang pertama kali matang gonad ikan yaitu 41,6 dan $42,5 \mathrm{~cm}$. Kondisi seperti ini walau secara alamiah kelestarian populasi dapat dipertahankan, jika tidak diimbangi dengan pengelolaan penangkapan dapat beresiko terhadap keseimbangan stok ikan dimana ikan yang tertangkap belum mengalami pemijahan.

\section{PERSANTUNAN}

Tulisan ini merupakan kontribusi dari hasil penelitian karakteristik biologi perikanan, habitat sumberdaya dan potensi produksi sumberdaya ikan di WPP 573 T.A 2016 di Balai Riset Perikanan Laut, Jakarta. Terimakasih penulis sampaikan kepada Bapak Drs. Suwarso, M.Si atas saran dan masukannya dalam penulisan karya tulis ilmiah ini.

\section{DAFTAR PUSTAKA}

Afonso-Dias, I., Reis, C., \& Andrade, P. (2005). Reproductive aspects of Microchirus azevia (Risso, 1810) (Pisces: Soleidae) from the south coast of Portugal. Scientia Marina. 69 (2), 275-283. https:// doi.org/10.3989/scimar.2005.69n2275

Anonimus. (2017). Statistik perikanan tangkap di laut menurut wilayah pengelolaan perikanan Negara Republik Indonesia (WPP-NRI) 2005-2016. Jakarta: Direktorat Jenderal Perikanan Tangkap-Kementerian Kelautan dan Perikanan.

Arai, T., Kotake, A., Kayama, S., Ogura, M., \& Watanabe Y. (2005). Movements and life history patterns of the skipjack tuna (Katsuwonus pelamis) in the western Pacific, as revealed by otolith $\mathrm{Sr}$ : Ca ratios. Journal of the Marine Biological Association of the United Kingdom. 85(5), 1211-1216. https://doi.org/10.1017/ S0025315405012336

Bal, D. V., \& Rao, K. V. (1984). Marine fisheries (p. 491). New Delhi : Tata McGraw-Hill Publishing Company.

Dueri, S., Faugeras, B., \& Maury, O. (2012). Modelling the skipjack tuna dynamic in the Indian Ocean with APECOSM-E: Part 1. Model Formulation. Ecological modelling. 245, 41-54. https://doi.org/10.1016/ j.ecolmodel.2012.02.007. 
Effendie, M. I. (1997). Biologi Perikanan (p. 163). Penerbit Yayasan Pustaka Nusatama. Yogyakarta.

Effendie, M. I. (2002). Biologi Perikanan (p. 163). Penerbit Yayasan Pustaka Nusatama. Yogyakarta.

Froese, R., \& Pauly, D. (2011). FishBase: Katsuwonus pelamis. World Wide Web electronic publication. www.fishbase.org. version (02/2018).

Grande, M., Murua, H., Zudaire, I., \& Korta, M. (2010). Spawning activity and batch fecundity of skipjack, Katsuwonus pelamis, in the Western Indian Ocean. IOTC-2010-WPTT-47: 28 pp. (Unpublished).

Hartaty, H., \& Arnenda, G. L. (2019). Penentuan ukuran pertama kali matang gonad (Lm) cakalang (Katsuwonus pelamis Linnaeus, 1758) di Samudra Hindia Selatan Bali. J.Lit.Perikan.Ind. 25(2), 135-145. http://dx.doi.org/ 10.15578/jppi. 25.2.2019.135-145

Hidayat, T., Noegroho, T., \& Wagiyo, K. (2017). Struktur ukuran dan beberapa parameter populasi ikan cakalang (Katsuwonus Pelamis, Linnaeus, 1758) di Samudra Pasifik Utara Papua. BAWAL. 9(2), 113-121. http:// dx.doi.org/10.15578/bawal.9.2.2017.113-121

Holden, M. J., \& Raitt, D. F. S. (Eds.). (1974). Manual of Fisheries Sciences. Part 2. Methods of Resource Investigation and Their Application (p. 214). FAO Fish, Tech.Pap. (115). Rev. 1

Indian Ocean Tuna Commission. (2013). Report of the Fifteenth Session of the IOTC Working Party on Tropical Tunas. San Sebastian, Spain, 23-28 Oktober 2013. 93 p.

IOTC-WPNT06. (2016). Report of the 6th Session of the IOTC Working Party on Neritic Tunas. Mahe, Seychelles 21 - 24 June 2016. IOTC-2016-WPNT06R[E], p. 89 .

Jamal, M., Sondita, M. F. A., Haluan, J., \& Wiryawan, B. (2011). Pemanfaatan Data Biologi Ikan Cakalang (Katsuwonus pelamis) dalam Rangka Pengelolaan Perikanan Bertanggung Jawab di Perairan Teluk Bone. Jurnal Natur Indonesia. 14(1), 107-113. https://doi.org/ 10.31258/jnat.14.1.107-113

Jatmiko I., Hartaty, H., \& Bahtiar, A. (2015). Biologi reproduksi ikan cakalang (Katsuwonus pelamis) di Samudra Hindia bagian Timur. BAWAL. 7(2), 87-94. http://dx.doi.org/10.15578/bawal.7.2.2015.87-94
King, M. (2007). Fisheries biology, assessment and management (p.381) Second edition. Blackwell Sciencetific Publication, Oxford.

Lambert, Y., Yaragina, N. A., Kraus, G., Marteinsdottir, G., \& Wright, P. J. (2003). Using environmental and biological indices as proxies for egg and larval production of marine fish. Journal of Northwest Atlantic Fishery Science. 33, 115-159. DOI: 10.2960/ J.v33.a7.

Mardlijah, S., \& Patria, M. P. (2012). Biologi reproduksi ikan madidihang (Thunnus albacares Bonnatere 1788) di Teluk Tomini. BAWAL, 4(1), 27-34. http://dx.doi.org/ 10.15578/bawal.4.1.2012.27-34

Mugo, R., Saitoh, S. I., Nihira, A., \& Kuroyama, T. (2010). Habitat characteristics of skipjack tuna (Katsuwonus pelamis) in the western North Pacific: a remote sensing perspective. Fisheries Oceanography. 19(5), 382-396. https://doi.org/10.1111/j.1365-2419.2010.00552.x

Nikijuluw, V.P.H. (2009). Status sumberdaya ikan tuna Samudra Hindia: Implikasinya bagi Indonesia. J.Kebijak.Perikan.Ind, 1(1), 32-44. http://dx.doi.org / 10.15578/jkpi.1.1.2009.31-44

Nugraha, B., \& Mardlijah, S. (2008). Beberapa aspek biologi cakalang (Katsuwonus pelamis) yang didaratkan di Bitung, Sulawesi Utara. BAWAL, 2(1), 45-50. http:// dx.doi.org/10.15578/bawal.2.1.2008.45-50

Nurdin, E., Taurusman, A.A., \& Yusfiandayani, R. (2012). Struktur ukuran, hubungan panjang-bobot dan faktor kondisi ikan tuna di Perairan Prigi, Jawa Timur. BAWAL, 4(2), 67-73. http://dx.doi.org/10.15578/ bawal.4.2.2012.67-73

Nurdin, E., \& Panggabean, A. S. (2017). Musim penangkapan dan struktur ukuran cakalang (Katsuwonus pelamis Linnaeus, 1758) di sekitar rumpon di perairan Palabuhanratu. J.Lit.Perikan.Ind, 23(4), 299-308. http://dx.doi.org/10.15578/jppi. 23.4.2017.299-308

Offem, B. O., Ayotunde, E. O., \& Ikpi, G. U. (2008). Dynamics in the reproductive of Heterobranchus longifilis Val. (Pisces: 1840) in the wetlands of Cross River, Nigeria. Research Journal of Fisheries and Hydrobiology. 3(1), 22-31.

Rachmawati, P. F., \& Hartati, S. T. (2017). Aspek biologi ikan layur (Lepturacanthus savala; Cuvier, 1829) di perairan Pangandaran, Jawa Barat. BAWAL, 9(2), 133143. http://dx.doi.org/10.15578/bawal.9.2.2017.133-143 
Rao, T.A., \& Sharma, SV. (1984). Reproductive biology of Mystus vittatus (Bloch) (Bagridae: Siluriformes) from Guntur, Andhra Pradesh. Hydrobiologia, 119(1), 2126. https://doi.org/10.1007/BF00016861

Restiangsih, Y.H., \& Amri, K. (2018). Aspek biologi dan kebiasaan makan ikan cakalang (Katsuwonus pelamis) di laut Flores dan sekitarnya. BAWAL, 10(3), 187-196. http://dx.doi.org/10.15578/bawal.10.3.2018.187-196

Rochman, F., Nugraha, B., \& Wujdi, A. (2015). Pendugaan parameter populasi ikan cakalang (Katsuwonus Pelamis, Linnaeus, 1758) di Samudra Hindia Selatan Jawa. BAWAL, 7(2), 77-85. http://dx.doi.org/10.15578/ bawal.7.2.2015.77-85

Saputra, S.W. (2005). Dinamika populasi udang jari (Metapenaeus elegans de man) dan pengelolaannya di Laguna Segara Anakan Kabupaten Cilacap Jawa Tengah. Disertasi Program Pasca Sarjana Institut Pertanian Bogor. Bogor.

Saputra, S.W., Soedarsono, P., \& Sulistyawati, G. A. (2009). Beberapa aspek biologi ikan kuniran (Upeneus spp.) di Perairan Demak. Jurnal Saintek Perikanan. 5(1), 16. https://doi.org/10.14710/ijfst.5.1.1-6

Sparre, P., \& Venema, S.C. (1999). Introduksi pengkajian stok ikan tropis. Badan Penelitian dan Pengembangan Perikanan. Terjemahan dari Introduction to tropical fish stock assessment. FAO Fish Tech. Paper 306(1), $376 \mathrm{p}$.

Steel, R. G. D., \& Torie, J. H. (1981). Principles and procedure of statistic (p. 748). Second edition McGraw Hill Book Company, Inc. New York.
Sulistiono, Mia, R. J., \& Ernawati, Y. (2001). Reproduksi ikan belanak (Mugil dussumieri) di perairan Ujung Pangkah Jawa Timur. Jurnal Iktiologi Indonesia, 1(2):31-37. https://doi.org/10.32491/jii.v1i2.200

Suwarso., Ernawati, T., \& Hariati, T. (2015). Biologi reproduksi dan dugaan pemijahan ikan kembung (Rastrelliger brachysoma) di pantai utara Jawa. BAWAL, 7(1), 9-16. http://dx.doi.org/10.15578/ bawal.7.1.2015.9-16

Udupa, K.S. (1986). Statisticalmethod of estimating the size at first maturity in fishes. ICLARM, Metro Manila, Fishbyte. 4 (2).8-10.

Uktolseja, J.C.B. (1989). The status of the Indonesian tuna fisheries. Report of the 3rd Southeast Asian Tuna Conference. Bali, Indonesia. 22 - 24August, 1989. IPTPFAO: 66-81.

Wahyuningsih, Prihatiningsih., \& Ernawati, T. (2013). Parameter populasi ikan kakap merah (Lutjanus malabaricus) di Perairan Laut Jawa bagian timur. BAWAL, 5(3): 175-179. http://dx.doi.org/10.15578/ bawal.5.3.2013.175-179

Wujdi, A., Suwarso, \& Wudianto. (2013). Biologi reproduksi dan musim pemijahan ikan lemuru (Sardinella lemuru Bleeker, 1953) di Perairan Selat Bali. BAWAL, 5(1): 49-57. http://dx.doi.org/10.15578/ bawal.5.1.2013.49-57

Zedta, R. R., Tampubolon, P.A. R. P., \& Novianto, D. (2017). Estimasi parameter populasi ikan cakalang (Katsuwonus Pelamis, Linnaeus, 1758) di perairan Samudra Hindia. BAWAL, 9(3), 163-173. http:// dx.doi.org/10.15578/bawal.9.3.2017.163-173 